\title{
DEVELOPMENTAL PATTERNS AND BODY FAT CONTENT OF JUVENILE COMMON HAMSTERS (CRICETUS CRICETUS L.)
}

\author{
Marc Pluch, Carina Siutz* and Eva Millesi
}

Department of Behavioural Biology, University of Vienna, Althanstrasse 14, A-1090 Vienna, e-mail: carina.siutz@univie

* corresponding author

\begin{abstract}
The common hamster (Cricetus cricetus) is a facultative hibernator producing up to three litters per year. Juveniles born late in the season have less time to grow and prepare for the winter than early-born ones. We investigated a free-ranging population in an urban environment in Vienna, Austria. We compared body mass, proportion of body fat, as well as head, tibia and hind foot length between juveniles of first and second litters at natal emergence, four weeks post-emergence and shortly before onset of hibernation. In addition we tested for differences in growth rates during the first four weeks after emergence and for potential effects of sex and litter size. Capture-mark-recapture techniques were applied. Body fat content was calculated using a multiple regression model integrating morphometric parameters. At natal emergence, second litter offspring were larger and heavier than those of first litters. Litter size did not account for these differences. During the first week after natal emergence, first litter pups gained body mass faster, and during the first two weeks also showed faster head and tibia growth rates than second litter pups. Four weeks after natal emergence, however, second litter juveniles were still larger and heavier than first litter ones. Body fat content four weeks post-emergence did not differ between first and second litters but decreased with litter size. Shortly before onset of hibernation, however, first litter juveniles, which had more time to grow and accumulate body fat, exceeded second-litter ones in all measured parameters. In all litters investigated, we found no sex difference at natal emergence but males were heavier and larger than females four weeks thereafter demonstrating that the commonly known sexual dimorphism in this species developed during this period. Considering the time constraints late born juveniles face, the con-
\end{abstract}

Contribution of 26th Meeting of the International Hamster Workgroup, 15-17th November 2013, Poznań, Poland 
ditional advance at natal emergence is assumed to be adaptive by increasing the chances for these individuals to survive overwinter despite the limited time to prepare for the hibernation period.

Key words: birth date, postnatal development, body mass, body size, growth pattern

\section{INTRODUCTION}

Hibernation is an adaptation to periodically low ambient temperature and consequential seasonal energy shortage (Humphries et al. 2003). To survive the winter period, hibernators need sufficient energy reserves especially to enable the energetically costly arousals out of torpor (NEDERGAARD et al. 1990). In addition, some species like the common hamster spend extended periods at normal body temperatures in their burrows or even above ground (WASSMER 2004). The two main tactics to allocate energy reserves are building up adipose tissue and hoarding food caches (DAY and BARTness 2003, Humphries et al. 2003, NedergaArd et al. 1990), with common hamsters using both alternatives (Millesi et al. 2004) with different emphasis in males and females (SIUTz et al. 2012). In general, hibernators are seasonal breeders with a temporally limited reproductive period that requires adaptations in reproductive timing and energy allocation for the winter (Millesi et al. 2004, NeLson et al. 1990) to enable overwinter survival in adults and offspring. At our study site in Vienna, vernal emergence in common hamsters occurs from early March in males to April/early May in females and first copulations have been observed shortly after female emergence (Franceschini-Zink and Millesi 2008, Hufnagl et al. 2011a). After a gestation time of 17-21 days (KIRn 2004, Vohralik 1974) and about three weeks in the natal burrow, juveniles emerge above ground and are weaned shortly thereafter (Niethammer 1982, Seluga et al. 1996). While most hibernators reproduce only once per season (Millesi et al. 2004), common hamsters can have up to three litters per year (Endres 2004, Franceschini and Millesi 2005, Seluga et al. 1996). Average litter size at our study site was $4.3 \pm 2.1$ (mean $\pm \mathrm{SD}$ ) (Hufnagl et al. 2011a) and ranged from 1-9 pups per litter (FrANCESCHINI-ZINK and Millesi 2008). Previous studies showed that litter sizes of first litters in a season were larger than those of second litters (HufNAgL et al. 2011a, FranCESCHINIZiNK and MiLlesi 2008). The total number of weaned offspring was higher in females which emerged early in spring and increased with the number of litters per season (Franceschini-Zink and Millesi 2008). Although juvenile common hamsters immerge into their hibernacula later in the season than adults (ENDRES 2004, Franceschini and Millesi 2005, Niethammer 1982), they face rigid time constraints. They have to grow, find an appropriate burrow by taking over an abandoned one or building a new burrow (Seluga et al. 1996), and prepare for hibernation by gaining body fat and hoarding food. To accomplish these tasks, 
it is beneficial to have as much time as possible; however, the time span decreases with increasing birth date. These temporal constraints could be challenging for late-born juveniles and might lead to increased adrenal activity resulting in elevated glucocorticoid (GC) concentrations. Increased GC secretion over a longer period could inhibit growth rates, impair body condition and increase mortality rates. This is supported by the result that free-ranging lateborn juveniles had higher cortisol levels than early-born ones shortly before winter, and body mass, body fat and overwinter survival were lower in latecompared to early-born juveniles (Siutz and Millesi 2012). Moreover, it has been shown in a laboratory study (KIRN 2004) that later birth dates negatively affected juvenile body mass in autumn. In addition, maternal investment might decrease with advanced season due to limited energy reserves of the females.

The aim of our study was to investigate differences in body mass, body fat content and structural body size between juveniles of females' first and second litters at natal emergence, during the early post-emergence period and shortly before immergence into their hibernacula. Based on previous results we hypothesized second litters to contain fewer offspring but, assuming similar maternal investment in first and second litters, higher body mass and/or body fat of second-litter juveniles at natal emergence. Due to the longer active period, we expected first-litter juveniles to be in better condition at the end of the season. We generally expected a negative effect of larger litter sizes on body mass, fat or size like it has been shown in numerous small mammal species (Guerra and Nunes 2001, Huber et al. 2001, Kaufman and Kaufman 1987, Neuhaus 2000).

\section{METHODS}

Study site and period

The study site was an urban area in Vienna (Austria, $+48^{\circ} 10^{\prime} \mathrm{N},+16^{\circ} 22^{\prime} 31^{\prime \prime} \mathrm{E}$ ) of approximately 2.7 ha. A population of free-ranging common hamsters inhabited green areas between and encircling buildings. The site consisted mainly of frequently mowed lawns with hedges, bushes and trees crossed by concrete pathways and mesh wire fences. Data collection was performed five days per week from March $29^{\text {th }}$ until October $5^{\text {th }} 2010$. Due to their bimodal daily activity pattern (Eibl-Eibesfeldt 1953, Schmelzer and Millesi 2008, Wendt 1989), hamsters were trapped from sunrise to the end of the morning activity period (around $10.30 \mathrm{am}$ ) and approximately twice per week from about $4 \mathrm{pm}$ until sunset. In addition, behavioural observations were carried out five days per week during the evening hours while females' breeding burrows particularly were monitored to detect juvenile emergence (see below). The daily sampling intervals for trapping and observing were chosen since the number of individuals active above ground as well as the individual frequency of above ground activity did not differ between morning and evening hours throughout the entire active season at our study site, neither in adults nor in juveniles (SIUTz et al., unpublished data). 
Field techniques

Adult and juvenile common hamsters were captured using peanut butter baited Tomahawk live traps, which were checked every 20 minutes at the latest. To avoid anaesthesia, the individuals were led into conical cotton sacks, laterally fitted with Velcro ${ }^{\circledR}$ strips and prepared with different openings to allow measurements of particular body parts. During the 5-10 minutes investigation, the morphometric parameters of body mass $( \pm 1 \mathrm{~g})$, head, tibia and hind foot lengths $( \pm 0.1 \mathrm{~mm}$ each) were recorded. Sex, reproductive status (testes width, vaginal opening, teat size) and age (adult, juvenile) were determined and date, time and trapping location ( $4 \times 4 \mathrm{~m}$ grid) were listed. Individual recognition was enabled by implanting subcutaneous transponders (PIT tag, Data Mars) and visual recognition by applying commercial hair dye in individual patterns on the dorsal region. Thereafter, the animals were released in front of their burrows (FrANCESCHINi et al. 2007) and were recaptured once per week. All animal manipulations were approved by the Austrian Ministry for Science and Research, Ethical Committee for Animal Welfare (BMWF-66.006/0007-II/10b/2009) and the City of Vienna (MA22-1216/2009).

Based on monitoring of body mass and reproductive status in adult females, parturition was identified by distinct body mass loss and increased teat size, partly with milk remains (Franceschini et al. 2007, Siutz and Millesi 2012). Juvenile natal emergence thus could be expected 17-20 days thereafter (EIBLEibesfeldt 1953, Endres 2004, Vohralik 1974). Natal emergence was defined as the day when the first juvenile of a litter was observed above-ground. If natal emergence was detected during evening observations, we trapped the juveniles later the next morning. Almost all young of a litter emerged within one day. In our study, litter size was defined as the number of juveniles that emerged from a female's breeding burrow. Litter number was defined as a females first or second litter of the season. Out of 128 recorded juveniles, only those of which natal emergence date, litter size and litter number (offspring of first or second litter) were doubtlessly known were used for analyses. Thus, litter mates $(n=47)$ of seven different litters (4 first, 3 second litters) were included in our statistical models. To increase sample size for statistical analysis of sex differences at natal emergence, all known litters were analysed, including those of which litter number was unknown. Pups of third litters (2 litters, 6 individuals) were excluded due to missing data points.

\section{Body fat content}

As described by SIUTz et al. (2012), body fat content was non-invasively calculated by a multiple regression model using the parameters body mass, head, tibia and foot length. The model was developed and validated by morphometric measurements of recently dead (within 12 hours) individuals and subsequent lipid extraction using a Soxhlet apparatus and petroleum ether as a solvent. Body fat analyses were not performed at natal emergence, because the present model is not valid for juveniles below a certain body mass. 


\section{Date and phase definitions}

Natal emergence was defined as day of natal emergence +2 days. The period afterwards was defined as post-emergence phase, lasting four weeks. We analysed all morphometric parameters at natal emergence and at the end of the post-emergence phase, i.e. at day $28 \pm 2$ after the day of natal emergence, which was defined as four weeks after emergence. Finally, the last data which could be recorded within the week before the juveniles' immergence into their hibernacula (between Sept $1^{\text {st }}$ and Oct $5^{\text {th }}$ ) where defined as prehibernation. Due to death (Kayser et al. 2003, Vohralik 1974) or dispersal (Seluga et al. 1996, WolfF 2007) during the season or missing data, the sample compositions and sample sizes differ between the phases. Analyses at natal emergence, four weeks thereafter, and during prehibernation included data of both male and female juveniles.

In addition, we analysed body mass gain and growth rates in juvenile males during the first 14 days interval post emergence (i.e. day of natal emergence until day $14 \pm 2$ thereafter) and during the second 14 days interval after natal emergence (post emergence day $14 \pm 2$ until day $28 \pm 2$, i.e. end of postemergence phase). Analyses were performed only for males due to insufficient data for females.

\section{Statistics}

Statistical analysis were performed in R 2.15.3 (Team R Development Core 2008). Linear models were computed, testing for normal distribution of model residuals by Shapiro-Wilk tests and for homoscedasticity using Levene tests. If model residuals were not normally distributed, the response variables were logtransformed. The full models included sex, litter size and litter number (first, second) and their two-way interactions as predictor variables. Model simplification was based on the AKAIKE information criterion (AIC) (AKAIKE 1973) corrected for small sample sizes (AICc) (Hurvich and Tsai 1991, Mazerolle 2011). The respective minimum adequate models are given in the tables including whether a predictor variable dropped out of the model based on AICc reduction. Due to dropping out of every interaction during the model simplification processes, ANOVA tables from the final models were computed using marginal (Type II) sums of squares. Because of unbalanced data at natal emergence concerning males and females, predictor variable sex was excluded from models at natal emergence. Instead we calculated the mean values of males and females of all mixed-sex litters and performed paired t-tests and a Wilcoxon signed-rank test from one not normally distributed sample to test for sex differences within litters at natal emergence. In addition, we tested for potential litter effects by computing linear models with mean values of the single litters as response variable and litter number as predictor variable (i.e., we calculated for each morphometric parameter mean values per litter and used them as response variables). Since $p$ values were similar and $\mathrm{R}^{2}$ values were almost the same compared to models with values of single individuals as a response variable, only results on the latter analyses are shown. 
Performed single correlations were Pearson's correlation tests, and to test for sex ratio bias Exact binomial tests for goodness of fit were conducted. To test for differences in the prehibernation immergence date between first and second litter offspring, a Mann-Whitney- $U$ test and for length of the active above-ground season between those two groups a student's t-test wee performed. Significance levels were set at $\mathrm{p}=0.05$ if not stated otherwise. Results are shown as means $\pm \mathrm{SD}$.

\section{RESULTS}

47 individuals of seven different litters (four first, three second litters) were used in our study. Litter sizes at natal emergence were 4, 7, 8, 12 and 4, 5,7 for the first (L1) and second litters (L2) respectively. A linear model showed no differences between litter sizes of first and second litters $\left(p=0.3, F_{1,5}=1.34\right.$, $\mathrm{n}=7$ ). First litters emerged from May $25^{\text {th }}$ to June $23^{\text {rd }}$ and second litters from July $28^{\text {th }}$ to August $2^{\text {nd }}$. Age at natal emergence was similar in first $(21.9 \pm 3.4 \mathrm{~d})$ and second litters $(22.8 \pm 2.5 \mathrm{~d}$; student's t-test: $\mathrm{t}=-0.41, \mathrm{p}=0.7, \mathrm{n}(\mathrm{L} 1 / \mathrm{L} 2)=4 / 3)$.

Body mass in adult females before gestation onset had no influence on litter size, mass or the average juvenile body mass at natal emergence (Pearson's correlation: $\mathrm{p}=0.54, \mathrm{p}=0.72, \mathrm{p}=0.36, \mathrm{n}=6$ respectively).

There was no biased sex ratio in first or second litters or in all litters pooled (Exact binomial tests for goodness of fit: $\mathrm{p}=0.36, \mathrm{n}=31 ; \mathrm{p}=0.40$, $\mathrm{n}=16 ; \mathrm{p}=0.28, \mathrm{n}=47$ respectively).

Immergence into hibernacula occurred from September $1^{\text {st }}$ until October $1^{\text {st }}$ with no significant difference between first- and second-litter individuals, but a tendency of later immergence in second-litter juveniles (Mann-Whitney $U$ test: $\mathrm{p}=0.058, \mathrm{n}(\mathrm{L} 1 / \mathrm{L} 2)=7 / 8)$. The duration of the active season differed significantly (student's t-test: $\mathrm{t}=13.22, \mathrm{p}<0.001, \mathrm{n}(\mathrm{L} 1 / \mathrm{L} 2)=7 / 8)$ and was on average more than 2.5 times longer $(112 \pm 12$ days $)$ in first- than in second-litter offspring (43 \pm 8 days).

All juvenile males captured during this study developed (at least temporarily) scrotal testes, whereas only two females showed an opened vagina. Time of birth did not affect gonad size since mean testes width was similar in first$(14.9 \pm 1.7 \mathrm{~mm})$ and second-litter males $(15.1 \pm 0.8 \mathrm{~mm}$; student's $\mathrm{t}$-test: $\mathrm{t}=-0.23$, $\mathrm{p}=0.82, \mathrm{n}(\mathrm{L} 1 / \mathrm{L} 2)=19 / 9)$.

\section{Effects of litter number}

At natal emergence, juveniles of second litters had larger head, tibia and foot lengths and were heavier than those of first litters (Table 1, Fig. 1). Four weeks after natal emergence, second-litter juveniles were still larger in all parameters and heavier than first-litter ones (Table 1, Fig. 1). Body fat was not affected by litter number, since this predictor dropped out during the model simplification process (statistics for this predictor at last appearance in the model: $\left.\mathrm{p}=0.17, \mathrm{~F}_{1,15}=2.06, \mathrm{n}=17\right)$. Shortly before immergence into hibernation, 
however, first-litter juveniles had higher body mass and larger head and tibia length compared to second-litter ones (Table 1, Fig. 1). Foot length was no longer influenced by litter number. During this phase, we also found significant differences in body fat content between first and second litters $\left(\mathrm{p}=0.005, \mathrm{~F}_{3,11}=12.62\right.$, $\left.\mathrm{R}^{2}=0.85, \mathrm{n}=15\right)$, being higher in first $(17.6 \pm 4.6 \%)$ than second ones $(12.6 \pm 4.9 \%)$.

Table 1. Effects of litter number. ANOVA tables from AICc based minimum adequate models only concerning differences in body mass, head, tibia and foot length (respective response variable in the model) between first- and second-litter juveniles (predictor variable litter number in the respective model) at natal emergence, four weeks thereafter as well as shortly before hibernation onset (phase). Due to AICc based model simplification, the following predictor variables were not included in the final models -: natal emergence: litter size in all models, for sex see methods; four weeks after emergence: litter size in all models, sex in the model applied for head length (see also Table 3); prehibernation: litter size in all models, sex in the head length-model (see also Table 3); litter number dropped out of the model applied for foot length and is thus not presented for this phase.

\begin{tabular}{lllllll}
\hline Phase & Response variable & $\mathbf{N}$ & df & $\boldsymbol{F}$ value & $\mathbf{R}^{2}$ & $\boldsymbol{p}$ value \\
\hline Natal emergence & Body mass & 32 & 1 & 80.02 & 0.72 & $<0.001^{* * * *}$ \\
& Head length & 32 & 1 & 87.29 & 0.74 & $<0.001^{* * * *}$ \\
& Tibia length & 31 & 1 & 79.46 & 0.72 & $<0.001^{* * *}$ \\
& Foot length & 29 & 1 & 70.09 & 0.70 & $<0.001^{* * * *}$ \\
4 weeks after emergence & Body mass & 19 & 1 & 59.36 & 0.76 & $<0.001^{* * * *}$ \\
& Head length & 18 & 1 & 25.37 & 0.59 & $<0.001^{* * * *}$ \\
& Tibia length & 14 & 1 & 34.21 & 0.74 & $<0.001^{* * * *}$ \\
& Foot length & 11 & 1 & 13.34 & 0.68 & $0.006^{* * *}$ \\
& Body mass & 15 & 1 & 11.25 & 0.72 & $0.006^{* * *}$ \\
prehibernation & Head length & 15 & 1 & 20.69 & 0.58 & $<0.001^{* * *}$ \\
& Tibia length & 15 & 1 & 11.07 & 0.75 & $0.006^{* * *}$ \\
\hline
\end{tabular}

Growth rates in males

We additionally analysed growth rates in male juveniles during the first four weeks after natal emergence. During the first two weeks, first-litter males grew faster in head and tibia lengths than second-litter ones (Table 2, Fig. 2). This was no longer the case during the second 14 days interval: neither litter number nor litter size affected growth rates (Table 2, Fig. 2). There were no significant results concerning body mass in either of the two 14 days intervals 
(A)

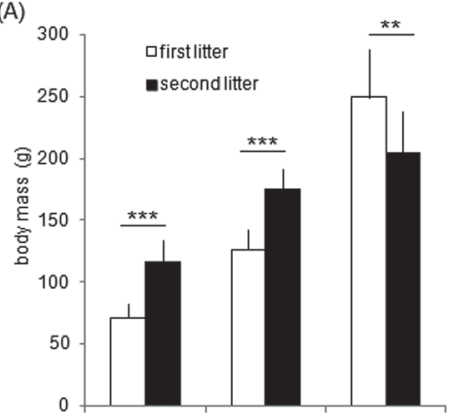

(C)

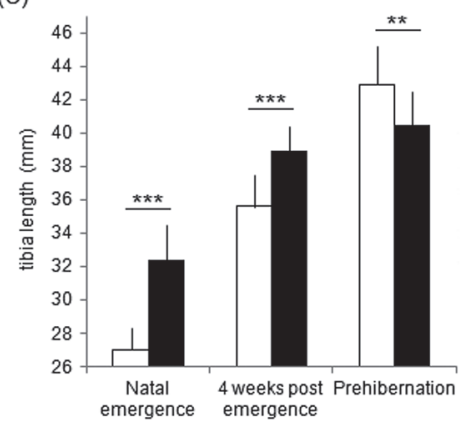

(B)

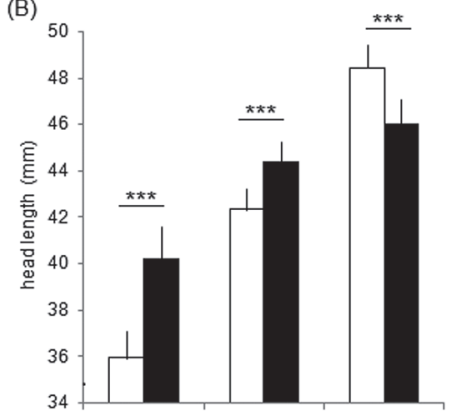

(D)

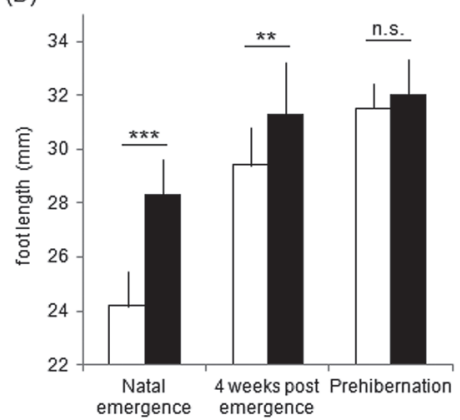

Fig. 1. Effects of litter number. Differences between first- and second-litter juveniles (means \pm SD) in body mass (A), head length (B), tibia length (C) and foot length (D) at natal emergence, four weeks after emergence and shortly before onset of hibernation. $* * * p<0.001, * * p<0.01$, n.s. $=$ not significant

(Table 2). However, when we analysed only the first week after natal emergence, first-litter males gained weight faster $(3.58 \pm 0.85 \mathrm{~g} /$ day $)$ than second-litter ones $\left(2.58 \pm 0.6 \mathrm{~g} /\right.$ day; linear model: $\left.\mathrm{p}=0.009, \mathrm{~F}_{1,11}=10.17, \mathrm{R}^{2}=0.43, \mathrm{n}=13\right)$.

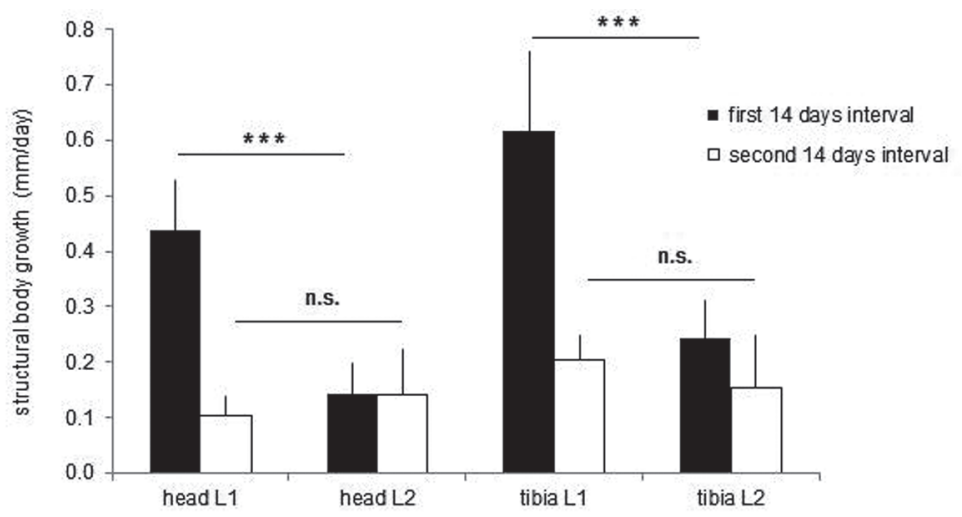

Fig. 2. Growth rates in males. Daily increase of head and tibia length in first- (L1) and second-litter (L2) males during the first and second-14-days-intervals after natal emergence ( sample sizes: L1-head $=7, \mathrm{~L} 1-$ tibia $=8, \mathrm{~L} 2$-each $=3$ ). ${ }^{* * *} \mathrm{p}<0.001, \mathrm{n} . \mathrm{s} .=$ not significant 
Table 2. Growth rates in males. ANOVA tables from AICc based minimum adequate models concerning gain of body mass and head and tibia growth per day during the first and second 14 days interval post-emergence. The following predictor variables were excluded from the final models based on AICc model simplification - first 14 days: litter size in all models; second 14 days: all the predictors, except for litter size in the model applied for body mass, dropped out in the respective models; similarly, none of the predictors affected foot length in both intervals, which is hence not shown in this table.

\begin{tabular}{|c|c|c|c|c|c|c|c|}
\hline Interval & Response variable & $\mathbf{n}$ & $F$ value & $\mathbf{R}^{2}$ & $p$ value & Predictor variable & df \\
\hline \multirow{3}{*}{$\begin{array}{l}\text { First } \\
14 \text { days }\end{array}$} & Body mass & 11 & 3.43 & 0.20 & 0.097 & litter number & 1 \\
\hline & Head & 10 & 25.71 & 0.73 & $<0.001 * * *$ & litter number & 1 \\
\hline & Tibia & 11 & 37.28 & 0.78 & $<0.001 * * *$ & litter number & 1 \\
\hline $\begin{array}{l}\text { Second } \\
14 \text { days }\end{array}$ & Body mass & 8 & 3.18 & 0.24 & 0.125 & litter size & 1 \\
\hline
\end{tabular}

\section{Sex differences}

At natal emergence, mean body mass $(p=0.18)$, head $(p=0.31)$, tibia $(p=0.17)$ and foot length $(p=0.04)$ did not differ between males and females within litters $(\mathrm{n}=5$ for all parameters, paired tests, Bonferroni corrected significance levels at $p=0.0125$ ). Four weeks after natal emergence, however, we found sex differences in that males had higher body mass and larger tibia and foot length than females after being corrected for litter number (Table 3, Fig. 3). These differences persisted

Table 3. Sex differences. ANOVA tables from AICc based minimum adequate models concerning only differences in body mass, head, tibia and foot length (respective response variable in the model) between male and female juveniles (predictor variable sex in the respective model) four weeks after natal emergence and shortly before hibernation onset (phase). Sex differences at natal emergence were analysed using paired t-tests (see methods) and the results are stated in the text. Due to AICc based model simplification, the following predictor variables were not included in the final models - natal emergence: litter size in all models, and since sex was not included at natal emergence, this phase is not presented in the table; four weeks after emergence: litter size in all models; prehibernation: litter size in all models, litter number in the model applied for foot length (see also Table 1); sex dropped out in the head length-models of four weeks after emergence and prehibernation and is thus not presented for these phases.

\begin{tabular}{lllllll}
\hline Phase & Response variable & $\mathbf{N}$ & df & $\boldsymbol{F}$ value & $\mathbf{R}^{2}$ & $\boldsymbol{p}$ value \\
\hline 4 weeks after emergence & Body mass & 19 & 1 & 5.61 & 0.76 & $0.031^{*}$ \\
& Tibia length & 14 & 1 & 13.95 & 0.74 & $0.003^{* *}$ \\
& Foot length & 11 & 1 & 14.73 & 0.68 & $0.005^{* *}$ \\
prehibernation & Body mass & 15 & 1 & 23.41 & 0.72 & $<0.001^{* * *}$ \\
& Tibia length & 15 & 1 & 28.70 & 0.75 & $<0.001^{* * *}$ \\
& Foot length & 11 & 1 & 25.91 & 0.71 & $0.004^{* *}$ \\
\hline
\end{tabular}


over the course of the season: males were still heavier than females and had larger tibiae and feet shortly before onset of hibernation (Table 3, Fig. 3). Head length, however, was not influenced by sex in any of the phases.

Body fat content was similar in both sexes four weeks after natal emergence (males: $8.4 \pm 4.9 \%$, females: $7.5 \pm 4.1 \%$ ). Shortly before onset of hibernation, however, males had significantly higher proportions of body fat than females (males: $17.6 \pm 3.3 \%$, females: $\left.9.5 \pm 4.1 \% ; \mathrm{p}<0.001, \mathrm{~F}_{3,11}=21.14, \mathrm{R}^{2}=0.85, \mathrm{n}=15\right)$.
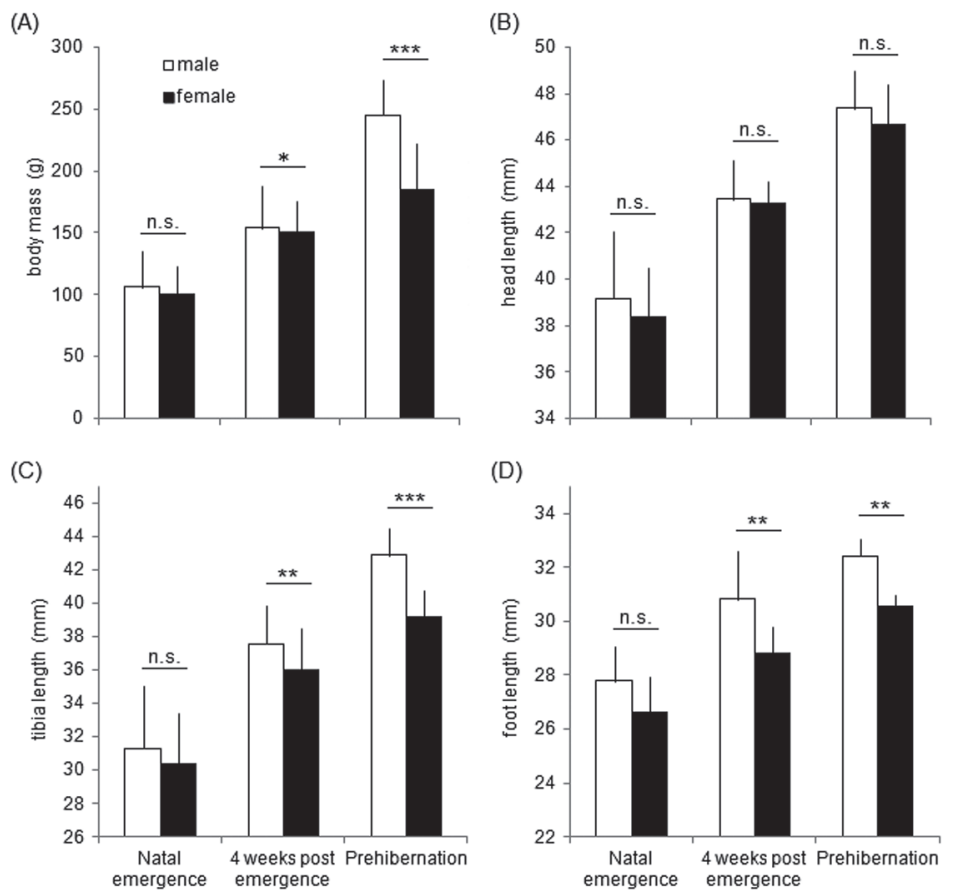

Fig. 3. Sex differences. Differences between males and females (means $\pm \mathrm{SD}$ ) in body mass (A), head length (B), tibia length (C) and foot length (D) at natal emergence, four weeks after emergence and shortly before onset of hibernation. n.s. = not significant, $* *$ p $<0.01, * * * p<0.001$

\section{Effects of litter size}

Litter size had no significant effect on body mass, size or sex during all three phases (Table 1 and Table 3). However, we found a positive relationship between litter size and body fat four weeks after natal emergence $\left(\mathrm{p}<0.001, \mathrm{~F}_{1.15}=25.54\right.$, $\left.\mathrm{R}^{2}=0.61, \mathrm{n}=17\right)$ as well as shortly before hibernation onset $\left(\mathrm{p}=0.017, \mathrm{~F}_{3,11}=7.94\right.$, $\mathrm{R}^{2}=0.85, \mathrm{n}=15$ ), with higher proportions of body fat in pups of smaller litters. 


\section{DISCUSSION}

Common hamsters can have up to three litters per season (ENDREs 2004, Franceschini-Zink and Millesi 2008, Weinhold and Kayser 2006). Earlier studies in Vienna however showed that most females raised two litters per season, a few females only one, and a third litter was observed rather exceptionally (Franceschini-Zink and Millesi 2008, Franceschini and Millesi 2005, Siutz and MiLlesi 2012). These results corresponded to those in our study period, in that only two females had three litters, but these were excluded from analyses due to low sample size. The range of 4-12 pups per litter in our study was similar to previous findings in Vienna (Franceschini-Zink and Millesi 2008, FranceschinI and Millesi 2005) and other sites (Endres 2004, Vohralik 1974). In our study, the first litters emerged between May $25^{\text {th }}$ and June $23^{\text {rd }}$ and second-litter juveniles emerged within six days after July $28^{\text {th }}$. These emergence dates were similar to earlier years in Vienna. Thus, reproductive timing and output in our study period can be described as unexceptional for common hamsters in Vienna.

The most intriguing result of our study was that second litter pups were larger and heavier than first litter ones at natal emergence and this difference persisted at least until four weeks thereafter.

One determining factor could be litter size. Large litter size is known to negatively affect body mass or postnatal growth rates in many species, for example Syrian hamsters (Mesocricetus auratus; Guerra and Nunes 2001) or European ground squirrels (Spermophilus citellus; Huber et al. 2001); in our study, however, we found no differences in litter size between first and second litters and accordingly, no effects of litter size on body mass or size were found.

We decided to pool the individual values of first and second litters, and performed a linear model with the mean values of the litters as response variables. Based on this result we can exclude that the differences were due to litter effects.

As our first measurements were taken at natal emergence, we cannot answer the question if the differences between first and second litters already existed in utero, at birth, or developed during the pre-emergence period in the breeding burrow. The duration juveniles stayed inside the burrow before natal emergence, however, was similar in first (18-25 d) and second litters (20-25 d); therefore, an age effect could be excluded.

Another explanation could be differences in the quality or quantity of food hoards in the natal burrow. Females carry food into the burrow throughout the active season and usually feed underground (SiUtz et al. 2012). Considering the fact that juvenile common hamsters can start to feed on solid food stored in the burrow at the age of six days (EIBL-Eibesfeldt 1953), seasonal changes in available food sources (HufNaGl et al. 2011b) may affect postnatal growth rates. Although it seems unlikely that food quality had increased from May to July in the study area, the availability of high-quality food items (e.g. seeds, berries) may change over time. As we have no information on quantity or quality of food hoards inside the burrow we cannot exclude such an effect. 
Furthermore, one could expect that a female's ability to invest in reproduction may decrease throughout the season due to increasing energetic constraints. Our results, however, indicate higher maternal investment per pup in second litters because these juveniles had higher body mass and larger size than those of first litters at a similar age. Since female body mass before gestation onset did not influence juvenile body mass at emergence, effects of maternal condition could be excluded. All females sampled in this study, however, were primiparous and therefore, higher maternal experience with increasing litter numbers could affect offspring condition, leading to larger and heavier second-litter juveniles.

We were not able to calculate the pups' body fat content at natal emergence because the morphometric method is not validated for this age class. Four weeks after natal emergence, however, body fat content was affected by litter size in that body fat decreased with litter size. This effect was found both in first and second litter pups. Although the pups were already weaned at this time, the strong litter size effect suggests that this relationship was determined during lactation.

Taken together, we assume that the better condition of second litter pups during the first weeks post-emergence was caused by higher maternal investment in later born offspring compared to earlier ones. This could have been accomplished by longer or more frequent lactation or by higher milk quality. We do not have any information on the quality of milk, but lactation durations of females ranged from 23-35 days in first litters and 19-27 days in second ones. Thus, lactation durations cannot account for the different juvenile condition and size at natal emergence and shortly thereafter.

During the first weeks following natal emergence, growth rates differed between first- and second-litter males (we had insufficient data of females) with first-litter males gaining body mass faster during the first week and having higher growth rates in head and tibia during the first two weeks after natal emergence compared to second-litter ones. Four weeks after natal emergence, however, second-litter juveniles were still heavier and larger than first litter ones, indicating that it takes longer than one month to compensate the deficit from natal emergence. And indeed, shortly before onset of hibernation, firstlitter juveniles were heavier, fatter and larger in head and tibia than second-litter ones.

At natal emergence, we found no sexual dimorphism, which corresponds to the results of Vohralík (1975), except for the hind foot length which differed between the sexes in VoнraLí (1975). Lacking sexual dimorphism might indicate similar maternal investment and/or growth rates in male and female offspring, at least until natal emergence. Four weeks after natal emergence, males were heavier and larger in tibia and foot lengths than females. Our findings therefore correspond to the literature stating that the sexual dimorphism appears at the age of three to seven weeks in this species (Niethammer 1982, Weinhold and KaYser 2006). Shortly before hibernation, males were heavier and larger than females, 
but like four weeks post emergence, there were no differences in head length. In addition to the known sex differences in body mass and size, we have previously shown sexual dimorphism in body fat content before hibernation in adult and juvenile common hamsters (Siutz et al. 2012).

In conclusion, the conditional advance during the first weeks after natal emergence did not enable later born pups to compensate the temporal deficits. This head start, however, could nonetheless increase their chances to survive over winter despite having less time to prepare for hibernation.

\section{WZORCE ROZWOJOWE I ZAWARTOŚĆ TKANKI TŁUSZCZOWEJ U MLODOCIANYCH OSOBNIKÓW CHOMIKA EUROPEJSKIEGO (CRICETUS CRICETUS L)}

\section{STRESZCZENIE}

Chomik europejski (Cricetus cricetus) jest gatunkiem hibernującym, który może mieć do trzech miotów rocznie. Osobniki urodzone pod koniec sezonu aktywności mają mniej czasu na wzrost i przygotowanie się do zimy niż młode urodzone na początku sezonu. Przeprowadziliśmy badania na wolno żyjącej, miejskiej populacji chomika we Wiedniu w Austrii. Porównaliśmy masę ciała, zawartość tkanki tłuszczowej, a także długość głowy, piszczeli oraz tylnej stopy pomiędzy osobnikami z pierwszego i drugiego miotu zaraz po pierwszym wyjściu z nory, cztery tygodnie po opuszczeniu nory oraz zaraz przed rozpoczęciem hibernacji. Dodatkowo porównaliśmy tempo wzrostu podczas czterech pierwszych tygodni od pierwszego opuszczenia nory oraz przeanalizowaliśmy dane w celu stwierdzenia obecności efektu płci i wielkości miotu. Dane pozyskaliśmy stosując metodę odłowów CMR. Zawartość tkanki tłuszczowej została obliczona na postawie modelu wielokrotnej regresji uwzględniając parametry morfometryczne. Potomstwo $\mathrm{z}$ drugiego miotu podczas pierwszego wyjścia z nory było większe i cięższe niż osobniki z pierwszego miotu. Różnica ta nie była powiązana z wielkością miotu. Podczas pierwszego tygodnia po wyjściu z nory osobniki z pierwszego miotu przybierały na masie szybciej, a także w pierwszych dwóch tygodniach wykazywały szybszy wzrost głowy i piszczeli. Jednakże cztery tygodnie po wyjściu z nory to młode z drugiego miotu były nadal większe i cięższe niż młode z pierwszego miotu. Badania zwartości tkanki tłuszczowej cztery tygodnie po wyjściu potomstwa z nory nie wykazały różnic pomiędzy pierwszym a drugim miotem, wykazały natomiast zależność między wielkością miotu a spadkiem zawartości tłuszczu. Krótko przed rozpoczęciem hibernacji to młode z pierwszego miotu, które miały więcej czasu na wzrost i zgromadzenie tłuszczu, przewyższyły osobniki z drugiego miotu we wszystkich badanych parametrach. W żadnym $\mathrm{z}$ badanych miotów nie zaobserwowano różnic pomiędzy płciami w trakcie pierwszego wyjścia młodych z nory. Jednak cztery tygodnie później to samce były większe i cięższe, co pokazuje, że dymorfizm płciowy obserwowany powszechnie u tego gatunku kształtuje się właśnie w tym okresie. Biorąc pod uwagę ograniczenie czasowe, z którym muszą się zmierzyć młode urodzone późno, zakłada się, że ich większe rozmiary i masa ciała mają na celu zwiększenie szans przetrwania zimy, pomimo ograniczonego czasu na przygotowanie się do hibernacji. 


\section{REFERENCES}

AKAIKE H. 1973: Information theory and an extension of the maximum likelihood principle. 2nd International Symposium on Information Theory, Tsahkadsor, Armenian SSR: 267-281.

DAY D.E. and BARTness T.J. 2003: Fasting-induced increases in food hoarding are dependent on the foraging-effort level. Physiology \& Behavior. 78: 655-668.

Eibl-Eibesfeldt I. 1953: Zur Ethologie des Hamsters (Cricetus cricetus L.). Zeitschrift für Tierpsychologie. 10: 204-254.

Endres J. 2004: Feldhamster (Cricetus cricetus). Ökoporträt 37, NVN/BSG/BSH.

Franceschini-Zink C. and Millesi E. 2008: Reproductive performance in female Common hamsters. Zoology 111: 76-83.

Franceschini C. and Millesi E. 2005: Reproductive timing and success in Common hamsters. Proceedings of the 12th Meeting of the International Hamsterworkgroup, Strasbourg, France: 63-66.

Franceschini C., Siutz, C., Palme R. and Millesi E. 2007: Seasonal changes in cortisol and progesterone secretion in Common hamsters. General and Comparative Endocrinology. 152: 14-21.

Guerra R.F. and Nunes C.R. d.O. 2001: Effects of litter size on maternal care, body weight and infant development in golden hamsters (Mesocricetus auratus). Behavioural Processes. 55: 127-142.

Huber S., Hoffmann I.E., Millesi E., Dittami J. and Arnold W. 2001: Explaining the seasonal decline in litter size in European ground squirrels. Ecography. 24: 205-211.

Hufnagl S., Franceschini-Zink C. and Millesi E. 2011a: Seasonal constraints and reproductive performance in female Common hamsters (Cricetus cricetus). Mammalian Biology. 76: 124-128.

Hufnagl S., Siutz C. and Millesi E. 2011b: Diet composition of Common hamsters (Cricetus cricetus) living in an urban habitat. Säugetierkdl. Inf. 8: 69-78.

Humphries M.M., Thomas D.W. and Kramer D.L. 2003: The role of energy availability in mammalian hibernation: a cost-benefit approach. Physiological and Biochemical Zoology. 76: 165-179.

Hurvich C.M. and Tsai C.-L. 1991: Bias of the corrected AIC criterion for underfitted regression and time series models. Biometrika. 78: 499-509.

Kaufman D.W. and Kaufman G.A. 1987: Reproduction by Peromyscus polionotus: number, size, and survival of offspring. Journal of Mammalogy 68: 275-280.

Kayser A., Weinhold U. and Stubbe M. 2003: Mortality factors of the Common hamster (Cricetus cricetus) at two sites in Germany. Acta Theriologica. 48: 47-57.

KIRN N. 2004: Ontogenese des Europäischen Feldhamsters (Cricetus cricetus) unter dem Einfluss verschiedener prä-und postnataler Photoperioden. Dissertation, Tierärztliche Hochschule Hannover.

Mazerolle M. 201:. AICcmodavg: model selection and multimodel inference based on (Q) AIC (c). R package version. Vol. 1.27.

Millesi E., Hoffmann I., Aschauer A. and Franceschini C. 2004: Reproduction and hibernation in females: a comparison of two sympatric ground-dwelling rodents. In: Barnes, B.M., CAREY, H.V., (eds) Life in the Cold - Evolution, Mechanisms, Adaptation, and Application. Institute of Arctic Biology, University of Alaska Fairbanks. 27: 367-375. 
Nedergaard J., Cannon B. and Jaenicke R. 1990: Mammalian Hibernation (and Discussion). Philosophical Transactions of the Royal Society of London. B, Biological Sciences. 326: 669-686.

Nelson R.J., Badura L.L. and Goldman B.D. 1990: Mechanisms of seasonal cycles of behavior. Annual Review of Psychology. 41: 81-108.

Neuhaus P. 2000: Weight comparisons and litter size manipulation in Columbian ground squirrels (Spermophilus columbianus) show evidence of costs of reproduction. Behavioral Ecology and Sociobiology. 48: 75-83.

Niethammer J. 1982: The Common hamster (Cicetus cricetus) (Linnaeus, 1758) - Hamster (Feldhamster). Handbuch der Säugetiere Europas, 2/1 Rodentia, Akademische Vertragsgesellschaft, Wiesbaden: 7-28.

Schmelzer E. and Millesi E. 2008: Activity patterns in a population of European hamsters (Cricetus cricetus) in an urban environment. Proceedings of 11 th Meeting of the International Hamsterworkgroup. Budapest, Hungary: 19-22.

Seluga K., Stubbe M. and Mammen U. 1996: Zur Reproduktion des Feldhamsters (Cricetus cricetus L.) und zum Ansiedlungsverhalten der Jungtiere. Abh. Ber. Mus. Heineanum. 3: 129-142.

Siutz C. and Millesi E. 2012: Effects of birth date and natal dispersal on faecal glucocorticoid concentrations in juvenile Common hamsters. Gen. Comp. Endocrinol. 178: 323-329.

Siutz C., Pluch M., Ruf T. and Millesi E. 2012: Sex Differences in Foraging Behaviour, Body Fat and Hibernation Patterns of Free-Ranging Common Hamsters. In: Ruf, T., Bieber, C., Arnold, W., Millesi, E. (eds) Living in a Seasonal World, Springer, Berlin: 155-165.

Team R - Development Core 2008: A language and environment for statistical computing. R Foundation Statistical Computing, 2008.

Vohralik V. 1974: Biology of the reproduction of the common hamster, Cricetus cricetus (L.). Vestnik Ceskoslovenske Spolecnosti Zoologicke. 38: 228-240.

Vohralík V. 1975: Postnatal development of the common hamster (Cricetus cricetus L.) in captivity. Academia.

WAssmer T. 2004: Body temperature and above-ground patterns during hibernation in European hamsters (Cricetus cricetus L.). Journal of Zoology. 262: 281-288.

Weinhold U. and Kayser A. 2006: Der Feldhamster. Die Neue Brehm-Bücherei Bd. 265. Westarp Wissenschaften, Hohenwarsleben.

Wendt W. 1989: Zum Aktivitätsverhalten des Feldhamsters, Cricetus cricetus L., im Freigehege. Säugetierkundliche Informationen. 3: 3-12.

Wolff J. O. 2007: Social biology of rodents. Integrative Zoology. 2: 193-204. 